\title{
高温高圧下における $\mathrm{Fe}-\mathrm{Al}-\mathrm{Si}$ 合金の機械的性質
}

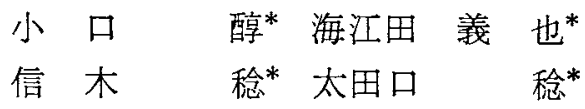

Atsushi Oguchi, Yoshinari Kaieda, Minoru Nobuki and Minoru Otaguchi : Mechanical Properties of an Fe-Al-Si Alloy under High Pressure and High Temperature.

In order to study the mechanical properties of brittle materials, bending tests have been carried out for a polycrystalline Fe-Al-Si alloy containing $6.22 \% \mathrm{Al}$ and $9.63 \% \mathrm{Si}$ (Senđust) under high pressure and high temperature up to $800 \mathrm{MPa}$ and $900^{\circ} \mathrm{C}$. The transition temperature from brittle to ductile decreased from 770 to $650^{\circ} \mathrm{C}$ by application of a pressure of $800 \mathrm{MPa}$. At lower temperatures, no distinct change in fracture stress due to testing temperature was seen at atmospheric pressure. However, under $800 \mathrm{MPa}$, it increased with increasing temperature and the difference was almost the same order of magnitude as the applied pressure. At temperatures higher than about $860^{\circ} \mathrm{C}$ at atmospheric pressure and about $720^{\circ} \mathrm{C}$ under $800 \mathrm{MPa}$, the material could be deformed largely. But, many grain boundary cracks were induced on the specimen deformed at atmospheric pressure, while the formation of cracks was suppressed under high pressure. The pressure required for a rapid increase in ductility without cracks at a given temperature was almost the same order as the yield stress at that temperature.

(Received September 1, 1977)

\section{I. 緒言}

金属材料の応力ーひずみ曲線に及济す静水圧の影響につ いてはすでに多くの研究がなされて沏り，筆者らもこれに ついていくつかの結果を報告してきた。また脆性一延性遷 移現象や，延性(破断较り)に対する代力の効果についても いるいると議論がなされている。これらの結果を概観する と，ます応力ーひずみ曲線は静水压によって一般にはあま り大きな変化は示さないといえる。．その変化は材料の弾性 定数の艮力による変化のオーダーである(1) (5). てかて 変形中に相变態を生ずる場合には大きな変化が少られ $る^{(6)(7)}$. 一方，延性に対する静水圧の効果は大きく，大気 王下で脆性なるのあるいはごくわずかな塑性变形後急激に 破壞するものが，ある压力以上で大きな延性を示すように なる現象が知られている ${ }^{(8)}$ ．またこれ関連のある現象と して，脆性破壊応力が，静水圧下で上昇する場合としない 場合があるという報告(9)もされている。

このよらな現象はまた温度によっても影響を受けるか ら，正力と温度を同時に加克大場合の機珹的性質あるいは 破壊や変形の挙動は興味のある問題であるがこのような データはまだ十分得られているとはい光ない。

ここでは主として室温，大気压下で脆性な材料の，高温 高生下に拈ける機械的性質を調べる目的で，Fe-A1-Si 合 金(センダスト)を用い，900足, $800 \mathrm{MPa}$ までの条件下で 曲げ試験を行って，破壊応力，降伏応力，延性などについ て調べた結果を報告する。

\section{II. 材料および実験方法}

実験に用いた材料の化学分析值は A1:6.22\%, Si : 9.63 $\%$ ，残り Feであったここの鋳造材より断面 $3 \mathrm{~mm} \times 3 \mathrm{~mm}$, 長さ $20 \mathrm{~mm}$ の角柱状試験片を切り出し, 真空中で $950^{\circ} \mathrm{C}$, $3 \mathrm{~h}$ の焼鈍を行ったのち実験に用いた。な結晶粒径は約 $0.4 \mathrm{~mm}$ であった。

高温高圧下の曲壮試験に用いた実験装置は前報 ${ }^{(10)}$ の通 りであり, 試験条件としては曲げスパン長 $15 \mathrm{~mm} の 3$ 点

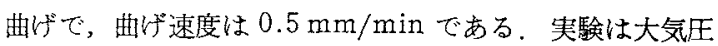
下，800 MPa 下で，温度を室温から $900^{\circ} \mathrm{C}$ の間で変化さ せて行い，曲げ荷重一たわみ曲線を求めた。なおこの際， 試料に与党る曲げたわ量は実験の都合上今回は $3 \mathrm{~mm}$ ま でとした。また破面の観察も市放せて行った。

\section{III. 実 験 結 果}

Fig.1 は大気圧下および $800 \mathrm{MPa}$ 中で得られた曲げ荷 重一たわみ曲線の例である。図中の数字は試駼温度 $\left({ }^{\circ} \mathrm{C}\right)$ を示している。大気压下では温度約 $700^{\circ} \mathrm{C}$ を゙ははとん

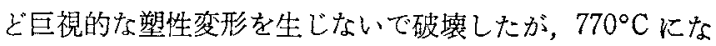

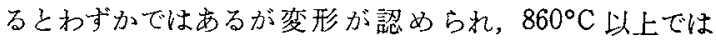
$3 \mathrm{~mm}$ 以上のたわ量をで破壊せずに変形が可能であっ た。一方 $800 \mathrm{MPa}$ 下では約 $650^{\circ} \mathrm{C}$ 以上で巨視的塑性変形 がみられはじめ， $720^{\circ} \mathrm{C}$ 以上では全て $3 \mathrm{~mm}$ 以上の曲げ たわ量を得ることができた。な拉，いずれの場合にる， 大きな変形を示与温度範囲ではほぼ平らな形となった。

\footnotetext{
* 金属材料技術研究所 (National Research Institute for Metals, Tokyo)
} 


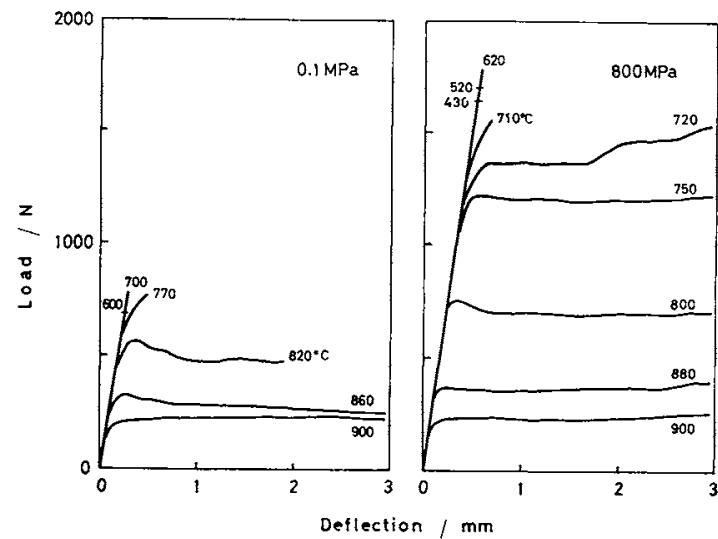

Fig.1 Examples of the bending load-deflection relation of an $\mathrm{Fe}-\mathrm{Al}-\mathrm{Si}$ alloy obtained at atmospheric pressure and under $800 \mathrm{MPa}$. Testing temperatures are indicated in the figure.

Fig.2は，Fig.1に例を示したような荷重一たわみ曲 楾から降伏応力 $\left(\sigma_{y}\right)$ 扣よび破壊応力 $\left(\sigma_{f}\right)$ を求めた結果を示 したるのである。これらの応力は次のよらにして求めた。

3点曲げの場合，たわ量が小さく弾性変形の範囲であ れば，引張および正縮の伈力が最大となるのは試料の表面 であってその值の絶対值は等しく，曲げ荷重 $L$ のき次 式によって表わせる。

$$
L=\frac{2}{3} \frac{a^{2} b \sigma}{l}
$$

ここで，lａ，bはそれぞれ曲げスパン長，試料の唇み方向

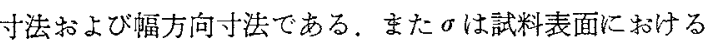
引張または正縮の応力である。本夷験の場合， $a=b=3$ $\mathrm{mm}, l=15 \mathrm{~mm}$ であって，厳密には試料断面に働くせん 断応力の影響を考慮に入れるべきであろうが，後に述べる ような理由によりここでは大よその傾向を論ずるに止める

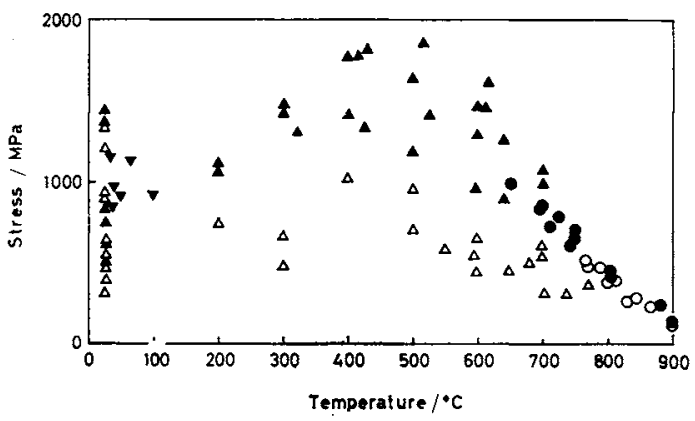

Fig.2 Fracture stress (triangles) and yield stress (circles) as a function of temperature. Open and black symbols represent the results obtained at atmospheric pressure and under $800 \mathrm{MPa}$, respectively. Downward triangles show the fracture stresses obtained under $800 \mathrm{MPa}$ at $10 \mathrm{w}$ temperatures after the specimens were held at $700^{\circ} \mathrm{C}$ for $20 \mathrm{~min}$ under the same pressure.
ので，式(1)がそのまま用いられるるのとする。

ますさ，試料が巨視的には弾性変形の範国内で急激に破壞 した場合には，その破壊時の荷重 $L$ を用いて式(1)より

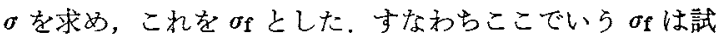
料の引張側表面に指ける最大引張応力である。

次に， $\sigma_{\mathrm{y}}$ は試料の引涱側表面が降伏を生ずるとき，この 表面に沿って働いている引張応力として求めた。この場 合，Fig.1飞示したよらな荷重－たわみ曲線から，試料表 面が降伏を生じた点を求めることは困難である。乙かし非 加工硬化性材料では，表面で降伏を生ずるときの曲げ荷重 $L_{\mathrm{e}}$ と, 試料断面全部が降伏するとさの荷重 $L_{0}$ との間に

$$
L_{0}=\frac{3}{2} L_{\mathrm{e}}
$$

の関係があり，またこの值 $L_{0}$ が曲げ荷重の極限となるこ とがわかっている。本実験の結果ではFig.1にみられる よらに，大きな曲げたわみ量が得られるような温度では， 荷重一たわみ曲線が平らとなり加工硬化は汪とんどないと 考えられるから，Fig.1の曲線で荷重がほぼ一定となった ところの值を $L_{0}$ とし式 $(2)$ より $L_{\mathrm{e}}$ を求め, これより式 (1) から $\sigma$ 妾得て $\sigma_{\mathrm{y}}$ とした。しかし塑性变形をしてもわ ずかであり，荷重が一定となる以前に破填してしまったも のについては，一応 Fig.1 の曲線の立上り部において，曲 線が弾性変形の関係からずれはじめる点を $L_{0}$ とてて用い た。いずれにせよこのよらにして求めた $\sigma_{\mathrm{y}}$ の值はそれほ ど厳密な議論には用いられないが，大よその傾向を諭ずる ことはできよう。

Fig.2にみられる通り， $\sigma_{\mathrm{y}}$ は温度の上昇と共に急激に低 下するが圧力による変化はデータのばらつき以内である。

一方 $\sigma_{f}$ に対する王力の効果は複雑である。気压下での of は室温から約 $500^{\circ} \mathrm{C}$ までははぼ一定とみなせるが，こ れ以上では温度の上昇上共に徐々に低下していくならにみ える.しかし $800 \mathrm{MPa}$ 下の $\sigma_{\mathbf{f}}$ の場合，低温では大気生 下の值にくらべてはっきりした差は認められないが，温度 が上昇すると $\sigma_{f}$ る上昇し， $400 \sim 500^{\circ} \mathrm{C}$ においては大気旦 下にくらべ大よを周囲王力の分 $(800 \mathrm{MPa})$ 位高くなるょう にみえる。

次に，破面の観察結果によれば，大気压下，800 MPa下 共低温においては粒内のへき開破壊であったが，約 $500^{\circ} \mathrm{C}$ 以上になると破面には粒界破填の占める割合が増加した。 そして巨視的塑性変形がみられる温度に近くなると破面は 大部分が粒界となった。

Photo.1は $3 \mathrm{~mm}$ の曲げたわ文量を与党た試料の引張 睢表面和よび側面を示す，大気圧下の場合，Fig.1に示し

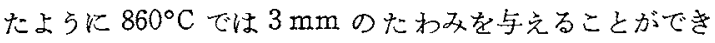
たが，その変形後にはこの写真に双られるように多くの粒 界クラックが観察された。 しかし $800 \mathrm{MPa}$ 中では $720^{\circ} \mathrm{C}$ に和いて，かなりの粒界过りの跡はみられるがクラック は発生しなかった。なたこのような光学蹎微鏡でみえる程 度の粒界过りの跡は低温では観察されなかったが，温度が 


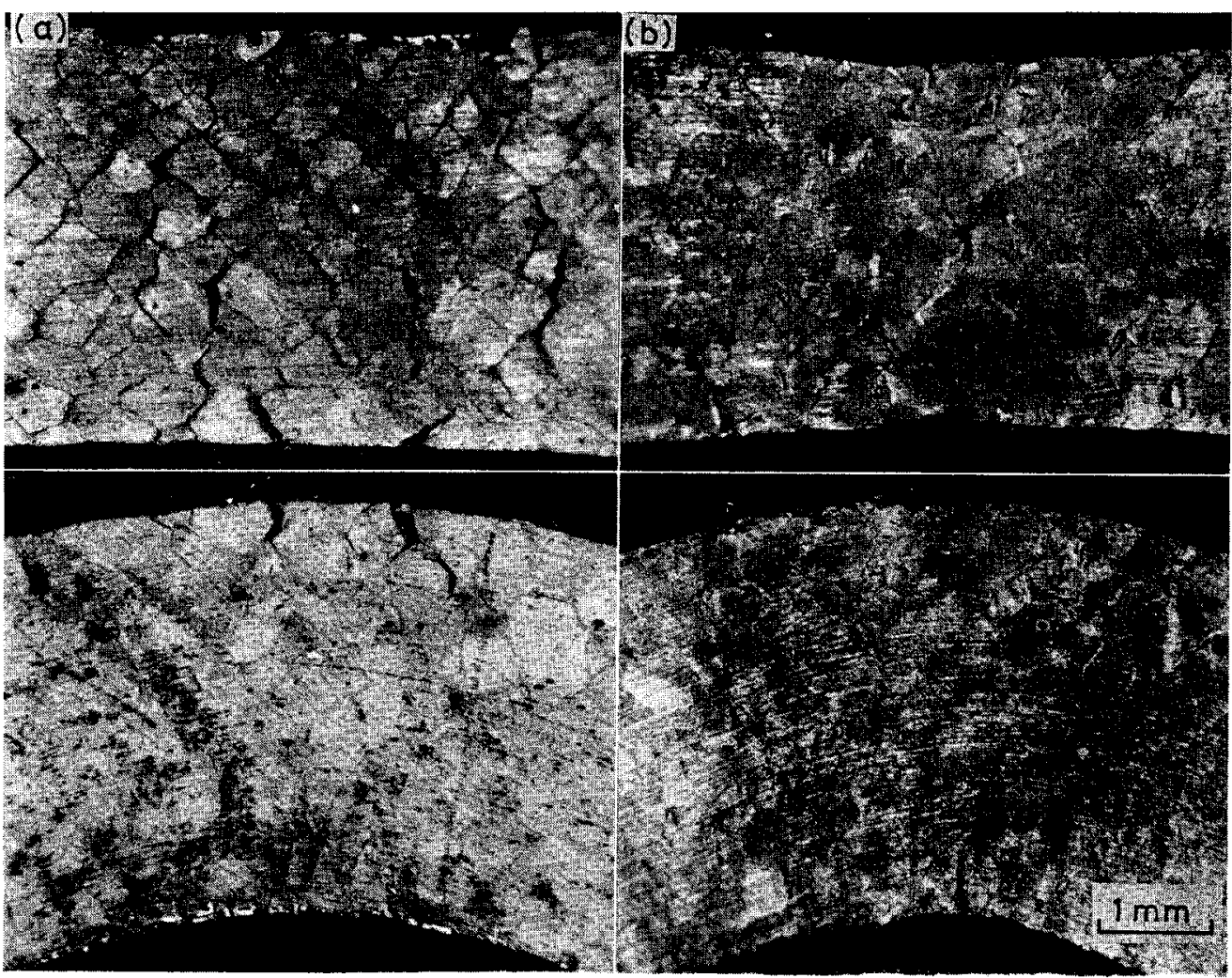

Photo.1 Surface of the specimens deformed at atmospheric pressure $(0.1 \mathrm{MPa})$ at $860^{\circ} \mathrm{C}$ (a) and under $800 \mathrm{MPa}$ at $720^{\circ} \mathrm{C}$ (b)

上昇して $800 \mathrm{MPa}$ では約 $650^{\circ} \mathrm{C}$ ，大気圧下では約 $750^{\circ} \mathrm{C}$ になると明瞭に観察された。

\section{IV. 検 討}

\section{1. 降伏応力}

一般に金属材料の降伏応力 $\left(\sigma_{\mathrm{y}}\right)$ は，静水王下で剈性率 $G$ の変化にほぼ等しい変化を示すと考光られる(1)〜(4)，この 材料については $G$ の変化のデータはないので $\sigma_{y}$ の変化を 推定することはできないが，一般に $G$ の变化はあまり大 きくない，前節において述べたよらに測定された $\sigma_{\mathrm{y}}$ の值 にはデータのばらつき以上の玨力による変化は認められな かった、すなわちこの材料に朊いてる試験された温度範目 では圧力による $\sigma_{y}$ の変化はあまり大きくはないといるよ 5 .

\section{2. 破壊応力}

ぜい珄材料の破壞底力 $\left(\sigma_{\mathbf{f}}\right)$ の静水生による変化につい て，坂田 $\boldsymbol{b}^{(9)}$ はガラスを用いて実験を行い，静水圧 $P$ 中 で測定した破壊応力 $\sigma_{\mathrm{f}}^{P}$ は $\sigma_{\mathrm{f}}^{P}=\sigma_{\mathrm{f}}^{0}+\alpha P$ で表わせると報告 している、ここで $\sigma_{f}^{0}$ は大気圧下での被壞応力， $\alpha$ は压力 の効果を表わす係数で，材料に被覆がなされているときに は1，被覆されていないときには0である。これは試料表面 には先在クラックがありここに压力媒体が浸入すると王 力の效果はなく $\alpha=0$ であるが，被覆をして圧力媒体の浸
入を防ぐとPによりクラックを闍じようとする力が動き， その分だ応力が高くなるまで破壊しないため $\alpha=1$ とな ると説明されている。すし材料表面にまったく欠陷がなけ れば $\alpha=1$ となる。

本実験の結果はFig.2 に示した通りであり，温度が低 いときには $P$ の効果はデータのばらつき以上には認めら れない，本実験では試料には被覆を施していないし，試料 表面には微細なクラックは存在するであろう。また曲げ試 験に衿いて，破壊は特に表面の久陷より発生しやすいか ら，本実験の低温に乱いてPの効果が殆んどみられなか ったのは圾田らの結果と類似のものと考方られる。

しかし温度が上昇すると $800 \mathrm{MPa}$ 下での $\sigma_{\mathrm{f}}$ は明らかに 上昇し，400 500 $\mathrm{C}$ で観察されたその堌加分は大よそ加 壳た周 国压力のオーダーであった。この $\sigma_{\rho}$ の上昇の原因 は定性的には以下のように考えることができる。

まず，室温 $200^{\circ} \mathrm{C}$ の低温では先在表面クラックが弾性 的に成長して破填し，この場合には先に述べたように坆田 ら (9)の考えに従うと考えられる。またこの材料の場合, 破 壊は粒内のへき開で生ずる。

しかし温度が上昇するとクラック先端に生ずる微視的塑 性変形の領域の大きさが増加し応力緩和を生ずるため，低 温に蛙けるような破壊はできない。その結果，一般の破壊 力学で論じられているように，大気圧下ではこのクラック の前方に新しいクラックを生じ，破壊はこれらのクラック 
が連結して発生する。しかし高静水生下の場合，このよう な新しいクラックは压力媒体から隔離された材料の内部に 発生しようとするもので，先代試料に被覆した場合の表面 クラックについて述べたと同し理由によりその発生が抑光 られるから，材料はこのょうな新しいクラックの発生なし に大きな塑性仕事をしながら破填し，破填応力は大気圧下

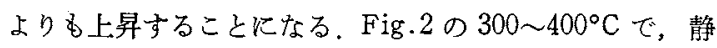
水王下の破壊応力 $\sigma_{\mathrm{f}}^{P}$ が上昇していくが，大気在下の破壞 応力 $\sigma_{\mathrm{f}}^{0}$ との差がまだ周囲圧力 $P$ 亿相当する分には達しな い過程はこのよらな理由によるものであるう。ただしこの 場合，塑性領域に粒界。含まれるが，粒界強度が粒内強度 より低くなるはどにはをだ温度が高くなかったため、クラ ックは粒内を通りへき開破面が見られたるのと思われる。 この上うにして温度の上昇と共に $\sigma_{\mathrm{f}}^{P} か ゙ \sigma_{\mathrm{f}}^{0}$ より增加し て行き, $\sigma_{\mathrm{f}}^{P}=\sigma_{\mathrm{f}}^{0}+P$ に達すると, いいか学れば村料中の真 の応力が，大気任下で新しいクラックを作る応力と等しく なると，むはやそ礼以上大きな塑性仕事をして破壊するよ りも新しいクラックを作って破填する方が容易となる。む しこのときの温度ですでに精界が粒内より弱くなっている と，塑性領域内に含ま礼る粒界では方りを生じており，粒 界の3重点などにクラックを発生して破壊する。すなお ち，この場合には上に述べた新しいクラックは粓界にでき

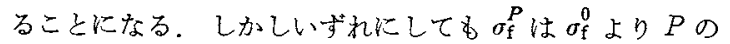
分だけ高くなることになる。

ところで本実験の場合，前述したように $800 \mathrm{MPa}$ 中で は約 $650^{\circ} \mathrm{C}$ に扮いて試料表面に粒界之りの跡が明瞭に観 察された。このよらに試料表面に粒界之りの跡が双られる といらことは，すでに云りがかなり広範囲に生じているこ

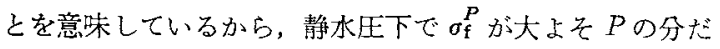
$け \sigma_{\mathrm{f}}^{0}$ より增加した温度範囲 $\left(400 \sim 500^{\circ} \mathrm{C}\right)$ でも，微視的 ではあるがクラック先端近傍では粒界沪りを生し゚，これが 破壤に関係していると考光てもよいであるう。は破壊も 約 $500^{\circ} \mathrm{C}$ の温度で粒内破壊から粒界破壊へ变化していた

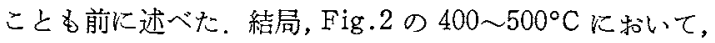
$\sigma_{\mathrm{f}}^{P}$ が大よそPに相当する分たけ $\sigma_{\mathrm{f}}^{0}$ 上り上算した実験事 実は上に述べたよらな理由によるすのであり，この材料の 場合，新しいクラックは粒界に発生したものであると考克 ることができよう。

ところで Shashkov ${ }^{(11)}$ は, $\mathrm{Cu}_{3} \mathrm{Si}, \mathrm{Ni}_{3} \mathrm{Sn}_{2}$ の金属間化合 物について，静水圧を加文ると粒界硬度は低下し，粒内硬 度は上昇すると報告している，旮してこの理由は，大気圧 下では粒界に偏析している不純物がスが高静水压下では粒 内へ搪散するためと考察している。るてこの上うな現象が 本実験に用いた材料でも生ずるとすれば，これは圧力中で $\sigma_{\mathbf{f}}$ が增加する現象に対し，上に述べた静水圧のいわば力学 的な効果之は別の一つの原因になり得る。すなわ占， Shashkov の考光を本実験にあてはめてみると，まず昖散 現象は温度が高い经ど生じやいから，高圧下では温度の
上昇と共に粒内硬度の上昇が生じ，その結果粒内へき開破

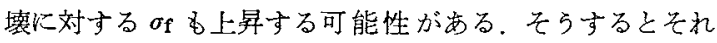

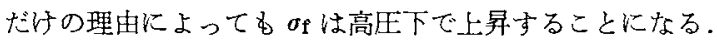
そころでこの現象は一種の組織变化によるもので，む高 压中で十分高温に長時間保持すれ标生じ，压力を保持しな がら温度だけを低下させれば残留すべきものである。そこ で舎際に $800 \mathrm{MPa}$ で $700^{\circ} \mathrm{C}$ に $20 \mathrm{~min}$ 保持したあと，た だちに温度のみ降下させ，同じ圧力中の室温で曲げ試験を 行って $\sigma_{f}$ を求めたところ，その結果をFig.2の中に下向 きの黒三角形で示したようにこの操作による $\sigma_{\mathrm{f}}$ の明らか な增加は認められなかった。

結局この材料の場合, Shashkov の述べた現象は 400〜

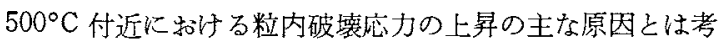
えられず，先に述べたような破壊の過程に対する生力の力 学的な効果が支配的であうう.

\section{3. 延性}

曲げ試験の場合，延性を表わす特性值として引張試駼に おける絞りのような值を用いることができない。をこで ここでは破壊後試料の引張表面に和ける幅収縮を求め, $\ln \left(w_{0} / w_{\mathrm{f}}\right)\left(w_{0}, w_{\mathrm{f}}\right.$ はそれぞれ試験前，試験後の試料の幅) の形で延性を表わすことを試みた。このよらにすると，变 形中に表面クラックを生じ，このクラックが開きながら変 形が進行していく場合，表面の見掛の引張ひずみの中には クラックの開口によるひずみが大きい割合を占め，幅の収 縮は小さく現われる。したがってこのような場合の延性を 小さく表わすことができ，延性の評価法の一つとして用い ることができょう、

Fig.3はこのようにして求めた延性の温度による变化を 大気圧下， $800 \mathrm{MPa}$ 下の場合について示したものである。 このように高温, 高静水压下では延性の著しい増加がみら れ，变形過程に持けるクラックの発生と成長が静水圧によ って抑止されているといえる。卞わなち，この場合には巨 視的な塑性変形によって粒界汇りを生じ，これによって粒

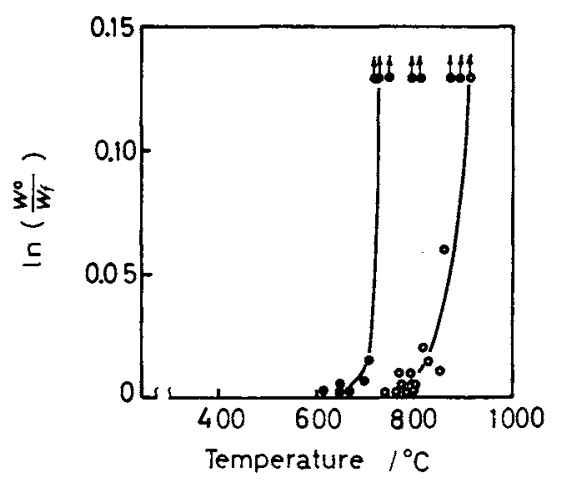

Fig. 3 Change in ductility (ln $w_{0} / w_{\mathrm{f}}$ ) as a function of temperature. Open and black symbols represent the results obtained at atmospheric pressure and under 800 $\mathrm{MPa}$, respectively. 
界にクラックが発生してこれが各々に連結しながら破壊が 進行していく，高蕰，大気圧下ではこれらの粒界クラック が試料の引張側表面へ開口して多くの表面クラックを形成 したるのと思われる。乙かし高静水圧下ではこれらの空隙 の発生は大きく抑充られるし，表面では粒界の竞りは拘束 されないから大きなひずみまでクラックの発生が起らず無 欠陷で変形ができるものと考无られる。

ところでFig.3にみられる通り，材料の延性が急に増

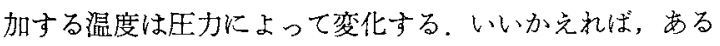
温度で, 延性が急に增加するような圧力が存在する.Fig.4 は温度 $800^{\circ} \mathrm{C}$ において，压力子延性の関係を示したもの で, 圧力約 $600 \mathrm{MPa}$ で延性の急激な增加が文られる。

Fig.5 は Figs.3，4の結果をまとめて，延性の急激な增加 を生ずる民゙力 $\left(P_{\mathrm{D}}\right)$ を温度の関数として示したるのである。 この压力の值は, 同図に破線で示した各温度における材料 の降伏応力に大上そ等しい，このような大きな延性が得ら れる高温では加工硬化にほとんど生じていないと考えられ るから，この値は材料の変形応力と考えてよいであろう。

そこで $P_{\mathrm{D}}$ とこの変形応力の関保について考光る。ところ で，本実験の場合，延性の急激な增加が生ずるのは，変形 に伴って粒界クラックが発生しかつ成長することが静水圧

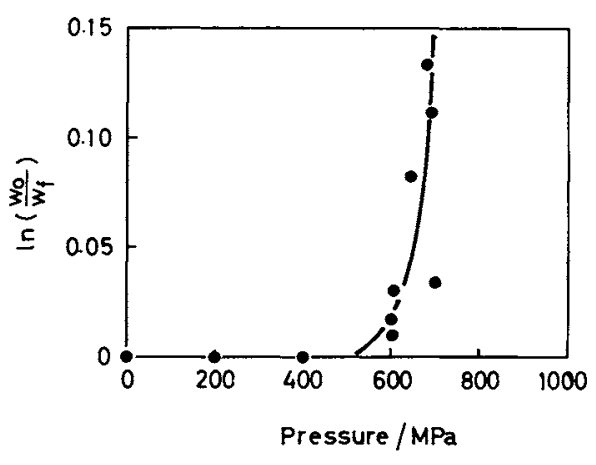

Fig.4 Change in ductility $\left(\ln w_{0} / w_{f}\right)$ as a function of pressure. The temperature was kept constant at $800^{\circ} \mathrm{C}$.

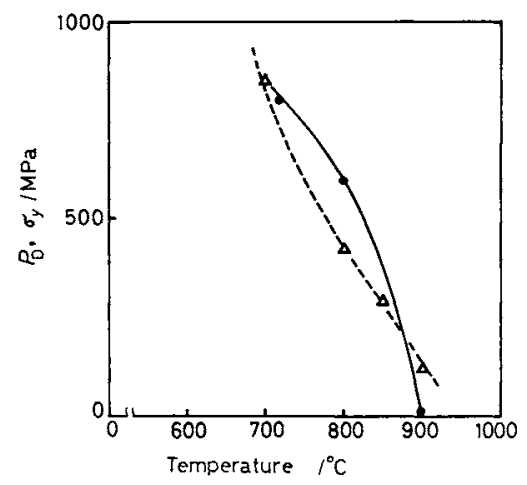

Fig.5 Yield stress $\left(\sigma_{y}\right.$, broken line) and ambient pressure required to obtaine a large plastic deformation $\left(P_{\mathbf{D}}\right.$, solid line) as a function of temperature.
下では抑止されるためであると考充られるが，ここではク ラックの発生を抑此する王力の条件が満足されればそれは 十分な条件であるという立場から以下に検討を行う。

McLean ${ }^{(12)}$ は Stroh ${ }^{(13)} の$ 理論を用い，粒界にクラック を生ずるための最小せん断応力 $\tau_{\min }$ を

$$
\tau_{\min }^{2}=\frac{12 \gamma G}{\pi L}
$$

として求めた．ここでイは単位面皘当りの表面エネルギ 一, $G$ は剛性率, Lは艺りの長さで結晶料径としている。 一般に $\gamma$ は $E a_{0} / 20$ ( $E$ : ヤング率， $a_{0}$ : 格子定数) の程度 であるから， $E=(2 \sim 3) G \fallingdotseq 300 \sigma_{\mathrm{y}}$ と仮定すると，式( 3 ) から $\tau_{\min } \fallingdotseq 0.1 \sigma_{\mathrm{y}}$ となり，1軸引張応力では $\sigma_{\min }=$ $2 \tau_{\min } \fallingdotseq 0.2 \sigma_{\mathrm{y}}$ となる。すすなわち材料の変形応力にくらへ てかなり低い引張応力でクラックは発生できることにな る.

ところで式(3)はクラック発生に必要なせん断応力の形 で表わされている。しかしすべての主応力が負の十分大き い㯈の場合には，孔九断応力成分が大気圧下での場合之同 じであってもクラックが発生するとは考光られない。すな わち，大気压下に怙いて式（3）で与兄られるようなせ九断 応力成分を生ずる引張応力がクラック発生の条件であっ て，静水压下ではこの引張応力が汪力の分だけ相殺される と考光るこ之ができよう。いか党れば艺りによってクラ ックを発生する場合，クラックを開こうとする引張応力成 分が存在しこれに対して静水圧が負の方向に働くためク ラックの発生が抑止される。したがって上で求めた $\sigma_{\min } \fallingdotseq$ $0.2 \sigma_{\mathrm{y}}$ は, 試料に働〈真の応力としてクラック発生の条件

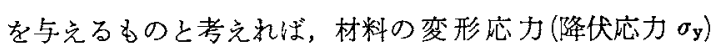
を $\sigma_{\min }$ 以下とするような圧力，すなわち約 $0.8 \sigma_{\mathrm{y}}$ を加克 ることによってクラックの発生を抑えることがでさること になる。

ところで,このクラック発生のための最小応力 $\sigma_{\min }$ と は，最むクラックが発生しやすいところにクラックを作る ための応力であって，一般にはさらに高い応力が必要とな る。したがって，最も容易な場所にクラックができてる他 の場所での発生が扔くれれば，試料全体としてみたとき巨 視的な変形が認められることもあるう。そのいみではクラ ック発生の条件と，巨視的塑性変形を生ずる条件とは必ず しも一致しない。むしろ先の条件に上り，最子容易な場所 にもクラックは発生しないとすれば，これは大きな塑性变 形を得るための十分条件となる。ささて，上に求めた $0.8 \sigma_{\mathrm{y}}$ の压力の值は大よそ $\sigma_{\mathrm{y}}$ のオーダーであって，Fig.5 の結 果を説明できるように思われる。しかし前記の計算には仮 定も含委れているしまた結晶䊀径や粒界の方位のばらつき もある。ささらにFigs.3，4の結果は延性の急激な増加を得 る温度，压力の関係であって，クラックの発生を完全に阴. 止し無限大の延性を得るるのではない，したがって上の考 えは敛密なるのではあり得ないが大体の傾向は示している ものと思われる。 


\section{V. 結言}

脆性な材料の高温高王下に和ける機珷的性質を調べる目 的で $\mathrm{A} 1$ 約 $6 \%$, Si 約 10\%を含む Fe-A1-Si 合金(センダ スト）の鋳造材を用い， $800 \mathrm{MPa}, 900^{\circ} \mathrm{C}$ ま゙の条件下で 曲げ試験を行って降伏応力, 破壊応力, 延性の変化を求め た。得られた結果は次の通りである。

(1)この材料は室温化拈いてはきわめてるるく，800 $\mathrm{MPa}$ 中ですへき開に上り破瓖した，しかし大気压下では 約 $770^{\circ} \mathrm{C}, 800 \mathrm{MPa}$ 中では約 $650^{\circ} \mathrm{C}$ 以上の温度で巨視的 な塑性变形を生ずるようになった。

(2) 巨視的な塑性変形を生することなく破壊する温度範 用では，破壊応力は大気厈下の場合室温から約 $500^{\circ} \mathrm{C}$ 亦 ではほぼ一定とみな过るが，これ以上では温度の上昇と共 に徐々に低下寸るよらにみられた。しかし高生力下におけ る破壊応力は，低温では大気在下での值にくらべてデータ のばらつき以上の差は示さなかったが，温度が上昇すると 增加し，400〜 $600^{\circ} \mathrm{C}$ に扎てその差は大上そ周田圧力と 闰楼度となった。

(3) 破壊様式は大気生下, $800 \mathrm{MPa}$ 下共, 低温では粒内 のへき開破壤であったが，約 $500^{\circ} \mathrm{C}$ 以上では粒界破壊を 生じはしか，巨視的塑性変形る生ずる温度以上ではほとん ど粒界破壊であった。

(4)大気压下では約 $860^{\circ} \mathrm{C}$ 以上， $800 \mathrm{MPa}$ 下では約 $720^{\circ} \mathrm{C}$ 以上の温度で，試料は $3 \mathrm{~mm}$ 以上のたわみ束で変 形が可能になった。しかし大気圧下で变形した場合には多
くの粒界クラックが発生した。一方高静水圧下ではこのク ラックの発生は㧕止され，欠陷の発生なしに大きな変形量 を得ることができた。また，ある温度においてこの大きな 延性を得るために必要な压力の值は，大よそその温度に和 ける材料の降伏応力と同程度であった。

\section{文献}

（1）吉田 進，小口 醇：日本金属学会誌，34(1970)， 401 .

（2）吉田 進, 小口 醇, 信木 稔：日本金属学会誌, $34(1970), 973$.

（3）小口 䤃, 言田 進, 信木 稔: 日本金属学会誌, $35(1971), 81$.

（4）小口 醇, 吉田 進, 信木 稔: 日本金属学会誌, 35 (1971) , 321 .

(5) J.O.Chua and A.L.Ruoff : J.Appl. Phys., 46 (1975) , 4659.

（6）小口 醇, 吉田 進：日本金属学会誌，36(1972), 550 .

（7）小口 醇, 吉田 進, 太田口 稔：日本金属学会 誌, $38(1974), 559$.

(8) M.Brandes: Mechanical Behaviour of Materials under Pressure, Elsevier Publishing Co., Ltd., (1970) , 236.

（9）圾田 勝，青木 繁: 材料，22(1973)，532。

(10) 小口 醇, 信木 稔, 太田口 稔, 海江田義也：日 本金属学会誌, 42(1978), 573 .

(11) D. P. Shashkov : Fiz. Metal. Metalloved., 31 (1971) , 1299.

(12) D.McLean : J.Inst. Metals, $85(1956-57), 468$.

(13) A.N.Stroh : Proc.Roy.Soc., 223 (1954), 404.

\section{$\mathrm{TiN}-\mathrm{Ni}$ 系混合圧粉体の焼結特性についで}

\section{三谷裕康** 永井 宏**福原幹夫***}

Hiroyasu Mitani, Hiroshi Nagai and Mikio Fukuhara: On the Sintering of the TiN-Ni Binary Powder Compacts.

Sintering characteristics of TiN-Ni mixed powder compacts were studied by heating them in a gas atmosphere of nitrogen, hydrogen or argon, or in a vacuum.

Shrinkage during sintering was disturbed in all of the gas atmospheres, whereas in a vacuum it was promoted remarkably accompanying the occurrence of the liquid phase and denitridation. The solubility of nitrogen in the nickel phase was very small and the composition of the titanium nitride phase equilibrated with the nickel phase was slightly lower than stoichiometric, ie., $\operatorname{TiN}_{0.99}$.

The solid solubilities of $\mathrm{TiN}_{1-x}$ in the nickel phase at various temperatures were determined by X-ray diffraction, and the maximum solubility of $5.2 \mathrm{wt} \%$ was found at $1350^{\circ} \mathrm{C}$.

(Received October 3, 1977)

** 大阪大学工学部金属工学科(Department of Metallurgy, Faculty of Engineering, Osaka University, Suita)

*** 大阪大学大学院 (Graduate School, Osaka University, Suita)

* 1975 年 4 月日本金属学会東京大会以発表 